\title{
KARAKTERISTIK TANAH DI BAWAH TEGAKAN JENIS VEGETASI MANGROVE DAN KEDALAMAN TANAH BERBEDA SEBAGAI INDIKATOR BIOLOGIS UNTUK TANAH TAMBAK DI KABUPATEN MAMUJU PROVINSI SULAWESI BARAT
}

\author{
Akhmad Mustafa, Rachmansyah, dan Kamariah \\ Balai Riset Perikanan Budidaya Air Payau \\ Jl. Makmur Daeng Sitakka No. 129, Maros 90512, Sulawesi Selatan \\ E-mail:akhmadmustafa@yahoo.com
}

(Naskah diterima: 21 Januari 2010; Disetujui publikasi: 11 Februari 2011)

\begin{abstract}
ABSTRAK
Kondisi lahan mangrove sangat ekstrem, sehingga vegetasi yang tumbuh merupakan vegetasi yang telah beradaptasi dan berevolusi dengan kondisi tersebut. Oleh karena itu, dilakukan penelitian yang bertujuan untuk mengetahui karakteristik tanah di bawah tegakan vegetasi mangrove dan kedalaman tanah berbeda yang dapat dijadikan indikator biologis untuk memprediksi karakteristik tanah untuk budidaya tambak. Pengukuran dan pengambilan contoh tanah dilakukan di bawah tegakan paku laut (Acrostichum aureum), bakau (Rhizophora apiculata), api-api (Avicennia alba), dan nipah (Nypa fruticans) masing-masing pada kedalaman tanah 0-0,25 m dan 0,50-0,75 $\mathrm{m}$ di hutan mangrove Kabupaten Mamuju Provinsi Sulawesi Barat. Kualitas tanah yang diukur langsung di lapangan adalah $\mathrm{pH}_{\mathrm{F}}, \mathrm{pH}_{\mathrm{Fox}}$, dan potensial redoks, sedangkan yang dianalisis di laboratorium adalah kandungan air, $\mathrm{pH}_{\mathrm{KCC}}, \mathrm{pH}_{\mathrm{OX}}, \mathrm{S}_{\mathrm{P}}, \mathrm{S}_{\mathrm{KC}}, \mathrm{S}_{\mathrm{POS}}, \mathrm{TPA}, \mathrm{TAA}, \mathrm{TSA}$, pirit, karbon organik, $\mathrm{N}$-total, $\mathrm{PO}_{4}, \mathrm{Fe}, \mathrm{Al}$, tekstur, dan nilai $\mathrm{n}$. Analisis ragam dilakukan untuk mengetahui perbedaan kualitas tanah antar vegetasi mangrove pada kedalaman yang sama, sedangkan Uji T dilakukan untuk mengetahui perbedaan kualitas tanah antar kedalaman pada vegetasi mangrove yang sama. Hasil penelitian menunjukkan bahwa tegakan bakau, api-api, nipah, dan paku laut yang tumbuh pada tanah sulfat masam Kabupaten Mamuju diklasifikasikan sebagai Sulfaquent dan Sulfihemits untuk kategori Kelompok Besar. $\mathrm{pH}_{\mathrm{F}}$ tanah pada vegetasi dan kedalaman tanah yang berbeda relatif sama, tetapi peubah kemasaman tanah lainnya menunjukkan bahwa tanah vegetasi paku laut memiliki potensi kemasaman yang lebih rendah dibandingkan dengan vegetasi lainnya. Kesuburan dan sifat fisik tanah vegetasi paku laut lebih mendukung untuk lahan budidaya tambak daripada vegetasi lainnya (bakau, api-api, nipah). Kualitas tanah pada setiap vegetasi relatif sama pada kedua kedalaman, kecuali tanah vegetasi paku laut dan api-api yang memiliki $\mathrm{pH}$ dan kandungan $\mathrm{PO}_{4}$ yang lebih tinggi pada kedalaman 0-0,25 m daripada kedalaman 0,50-0,75 m. Keempat vegetasi yang dikaji dapat dijadikan indikator biologis keberadaan tanah sulfat masam, tetapi vegetasi paku laut memiliki kualitas tanah yang lebih baik untuk lahan budidaya tambak. Disarankan bahwa pengambilan contoh tanah untuk analisis di laboratorium pada tanah vegetasi bakau dan nipah yang belum terganggu tidak perlu dilakukan pada kedalaman 0,50-0,75 m, kecuali untuk tujuan tertentu.
\end{abstract}

KATA KUNCl: mangrove, tanah, tambak, Sulawesi Barat 
ABSTRACT: Soil characteristics under different canopy types of mangrove vegetations and different soil depths as biological indicators for brackishwater ponds in Mamuju Regency West Sulawesi Province. By: Akhmad Mustafa, Rachmansyah, and Kamariah

\begin{abstract}
Soil condition in mangrove area is very extreme in terms of its characteristics. Vegetations that can grow in such area are those that have adapted and evolved to the condition. This research was conducted to study soil characteristics under various canopy types of mangrove vegetation and soil depths that can be used as biological indicators to predict soil characteristics for brackishwater ponds. Soil measurement and sampling were conducted under the canopyt of Acrostichum aureum, Rhizophora, apiculata, Avicennia alba, and Nypa fruticans at $0-0.25 \mathrm{~m}$ and 0.50-0.75 m of soil depth, respectively in mangrove forest of Mamuju Regency West Sulawesi Province. Soil qualities measured in the field were $\mathrm{pH}_{F}, \mathrm{pH}_{F O X}$, and redox potential, while those analysed in laboratory were water content, $\mathrm{pH}_{K C I}, \mathrm{pH}_{O X}, \mathrm{~S}_{P}, \mathrm{~S}_{K C \mathrm{I}}$, $S_{P O S}, T P A, T A A, T S A$, pyrite, organic carbon, total- $N, P O_{4}, F e, A l$, texture, and $n$ value. Analysis of variance was used to determine the difference of soil qualities among vegetations at the same soil depth and T Test was used to determine the difference of soil qualities at different soil depths of the same vegetation. The results show that Acrostichum aureum, Rhizophora, apiculata, Avicennia alba, and Nypa fruticans grow on the acid sulfate soils in Mamuju Regency classified as Sulfaquent and Sulfihemits in the Great Groups category. Soil $\mathrm{pH}_{\mathrm{F}}$ were the relatively the same on all vegetation areas and soil depths, but looking at acidity parameters, it shows that the soil under Acrostichum aureum has lower potential acidity than under other vegetations. Soil fertility and physical characteristics in the area of Acrostichum aureum vegetation is more suitable for brackishwater ponds than in other vegetation areas (Rhizophora apiculata, Avicennia alba, Nypa fruticans). Soil qualities under each vegetation at different soil depths were relatively the same, except for the $\mathrm{pH}$ and $\mathrm{PO}_{4}$ content of soil under Acrostichum aureum and Avicennia alba vegetation at 0-0.25 m of soil depth which was higher than those at 0.50-0,75 m soil depth. All vegetations that were evaluated in this research could be used as biological indicators in detecting the presence of acid sulfate soil, but Acrostichum aureum has been found to have better soil qualities for brackishwater pond than that of other vegetations. It is suggested that soil sampling in undisturbed soil of Rhizophora apiculata and Nypa fruticans for laboratory analysis are not needed at 0.50-0.70 $m$ of soil depth, except for certain purpose.
\end{abstract}

\title{
KEYWORDS: mangrove, soil, brackishwater pond, West Sulawesi
}

\section{PENDAHULUAN}

Kualitas tanah yang dapat dicirikan oleh karakteristik tanah merupakan salah satu faktor lingkungan yang dapat mempengaruhi produktivitas tambak sebab dapat mempengaruhi kualitas air, proses biologi, dan rekayasa tambak. Oleh karena itu, faktor kualitas tanah merupakan faktor yang dipertimbangkan dalam evaluasi kesesuaian lahan untuk budidaya tambak (Karthik et al., 2005). Setiap jenis tanah memiliki karakteristik tanah yang berbeda dan tentunya kualitas tanah yang berbeda pula.

Faktor pembentuk tanah merupakan faktor yang menentukan dalam pembentukan jenisjenis tanah. Walaupun faktor pembentuk tanah tersebut sebenarnya banyak, tetapi yang terpenting menurut Jenny (1941) dalam Schaetzl \& Anderson (2005), adalah: iklim, organisme, topografi, bahan induk, dan waktu. Yang termasuk faktor organisme dalam pembentukan tanah adalah vegetasi dan hewan, akan tetapi peran vegetasi lebih nyata dibandingkan dengan hewan (Hanafiah, 2005). Dalam hal ini, vegetasi dapat menentukan karateristik tanah yang terbentuk. Sebaliknya, vegetasi yang tumbuh di tanah tertentu dapat mencirikan sifat khas habitat yang merupakan bentuk adaptasi vegetasi terhadap habitat atau pengaruh habitat terhadap vegetasi. Hubungan antara vegetasi dan jenis tanah di daerah tropika seperti Indonesia umumnya kurang jelas, kecuali di tempat-tempat tertentu 
seperti di kawasan pesisir (Hardjowigeno, 2003). Vegetasi mangrove adalah vegetasi yang mendominasi kawasan pesisir yaitu dalam hutan mangrove yang merupakan lahan potensial untuk usaha budidaya tambak.

Tanah di bawah tegakan hutan mangrove tergolong kondisi yang ekstrem dalam hal salinitas, status oksidasi, tingkat kemasaman, ketersediaan nutrien, ukuran partikel tanah dan kestabilan tanah, serta pengaruh pasang surut. Oleh karena itu, hanya sedikit jenis vegetasi yang dapat bertahan hidup dan bersifat khas dan tentunya merupakan vegetasi yang telah melewati proses adaptasi dan evolusi pada kondisi tersebut. Menurut Ferreira et al. (2007), banyak faktor yang mempengaruhi zonasi vegetasi mangrove, tetapi jenis tanah adalah faktor yang paling jelas pengaruhnya dalam menentukan zonasi vegetasi mangrove. Oleh karena itu, jenis vegetasi mangrove dapat dijadikan indikator biologis dalam memprediksi karakteristik tanah di mana vegetasi mangrove tersebut tumbuh. Vegetasi mangrove jenis bakau (Rhizopora mucronata dan Rhizopora apiculata), nipah (Nypa fruticans), dan paku laut (Acrostichum aureum) adalah vegetasi yang umum dijumpai di kawasan pesisir dan telah digunakan sebagai indikator biologis keberadaan tanah sulfat masam (Sammut \& Lines-Kelly, 2000). Tanah sulfat masam adalah suatu istilah yang digunakan untuk menggambarkan sedimen pantai yang mengandung pirit $\left(\mathrm{FeS}_{2}\right)$ atau produk oksidasinya, termasuk peningkatan kandungan logam, sulfat $\left(\mathrm{SO}_{4}\right)$ dan kemasaman (Dent, 1986; Sammut \& Lines-Kelly, 2000; Schaetzl \& Anderson, 2005). Tanah sulfat masam dalam hutan mangrove umumnya ditumbuhi vegetasi api-api (Avicennia sp.), perepat atau pedada (Sonneratia sp.), tancang (Bruguiera sp.), bakau, dan nipah (Noor, 2004). Namun demikian, belum ada karakteristik yang lebih rinci dari tanah yang berada di bawah tegakan setiap jenis vegetasi mangrove yang tumbuh di kawasan pesisir itu serta pada kedalaman tanah yang berbeda. Karakteristik pada tanah yang lebih dalam perlu diketahui, mengingat bahwa dalam pembuatan tambak harus dilakukan penggalian tanah permukaan agar kedalaman air yang sesuai untuk budidaya tambak dapat dipenuhi. Kedalaman air yang dibutuhkan untuk budidaya udang windu, ikan bandeng, dan rumput laut minimal berturutturut 0,8; 0,6; dan 0,4 m. Kabupaten Mamuju Provinsi Sulawesi Barat (dahulu Provinsi Sulawesi Selatan) telah dilaporkan termasuk daerah yang masih memiliki lahan mangrove (Mustafa et al., 1988; ADB, 1997). Oleh karena itu, telah dilakukan penelitian yang bertujuan untuk mengetahui karakteristik tanah di bawah tegakan jenis vegetasi mangrove yang berbeda dan pada kedalaman tanah yang berbeda pula dengan harapan dapat menjadi indikator biologis dalam memprediksi karakteristik tanahnya dalam rangka evaluasi sumberdaya lahan untuk budidaya tambak.

\section{BAHAN DAN METODE}

Penelitian dilaksanakan di kawasan pesisir Kabupaten Mamuju Provinsi Sulawesi Barat. Hasil klasifikasi tidak terbimbing dari Citra Landsat-7 $\mathrm{ETM}^{+}$(Enhanced Thematic Mapper Plus) akuisisi 20 Juni 2004 serta 6 Januari, 3 Maret, dan 6 Oktober 2005 telah digunakan sebagai petunjuk awal dalam penentuan lokasi pengamatan. Penentuan lokasi pengamatan lanjutan dilakukan secara purposive (bertujuan) yaitu dengan memilih kawasan vegetasi mangrove tertentu.

Pengukuran dan pengambilan contoh tanah dilakukan di bawah tegakan dari vegetasi: paku laut (Acrostichum aureum), bakau (Rhizophora apiculata), api-api (Avicennia alba), dan nipah (Nypa fruticans) (Gambar 1). Pengukuran dan pengambilan contoh tanah dilakukan di tiga kawasan vegetasi mangrove untuk setiap jenis vegetasi mangrove, di mana tanahnya belum terganggu. Contoh tanah diambil dengan menggunakan bor tanah pada permukaan tanah $(0-0,25 \mathrm{~m})$ dan kedalaman tanah 0,50-0,75 m. Contoh tanah diambil pada tiga titik pengambilan untuk vegetasi yang sama pada satu kawasan vegetasi mangrove dan selanjutnya contoh tanah tersebut dikomposit untuk kedalaman yang sama. Titik-titik pengukuran dan pengambilan contoh tanah ditentukan posisinya dengan Global Positioning System (GPS) dan disajikan pada Gambar 2 dengan menggunakan Citra ALOS (Advanced Land Observing Satellite) AVNIR-2 (The Advanced Visible and Near Infrared Radiometer type 2) akuisisi 28 Juli 2009.

Kualitas tanah yang diukur secara in situ adalah $\mathrm{pH}_{\mathrm{F}}(\mathrm{pH}$ tanah yang diukur langsung di lapangan) dengan pH-meter (Ahern et al., 2004), $\mathrm{pH}_{\text {FOX }}$ ( $\mathrm{pH}$ tanah yang diukur di lapangan setelah dioksidasi dengan hidrogen peroksida $\left.\left(\mathrm{H}_{2} \mathrm{O}_{2}\right) 30 \%\right)$ dengan pH-meter (Ahern et al., 2004) dan potensial redoks diukur dengan redox-meter. Untuk analisis peubah kualitas 
tanah lainnya, maka contoh tanah yang ada dalam kantong plastik dimasukkan dalam cool box yang berisi es sesuai petunjuk Ahern et al. (2004). Karena seluruh contoh tanah adalah tanah sulfat masam, maka contoh tanah di-oven pada suhu $80^{\circ} \mathrm{C}-85^{\circ} \mathrm{C}$ selama $48 \mathrm{jam}$ (Ahern et al., 2004). Setelah kering, contoh tanah dihaluskan dengan cara ditumbuk pada lumpang porselin dan diayak dengan ayakan ukuran lubang $2 \mathrm{~mm}$ dan selanjutnya dianalisis di Laboratorium Tanah Balai Riset Perikanan Budidaya Air Payau di Maros. Kualitas tanah yang dianalisis di laboratorium meliputi kandungan air dengan metode gravimetri (Abdurachman et al., 2006), $\mathrm{pH}_{\mathrm{KCl}}(\mathrm{pH}$ dari ekstrak KCl) (McElnea \& Ahern, 2004a), $\mathrm{pH}_{\text {ox }}$ (McElnea \& Ahern, 2004b), $S_{p}$ (sulfur peroksida) (Melville, 1993; McElnea \& Ahern, 2004c), $S_{K C I}$ (sulfur yang diekstrak dengan $\mathrm{KCl}$ ) (Melville, 1993; McElnea \& Ahern, 2004d), $S_{\text {POS }}\left(S_{P}-S_{K C I}\right)$ (Ahern \& McElnea, 2004), TPA (Titratable Peroxide Acidity atau sebelumnya dikenal dengan Total Potential Acidity) (McElnea \& Ahern, 2004b), TAA (Titratable Actual Acidity atau
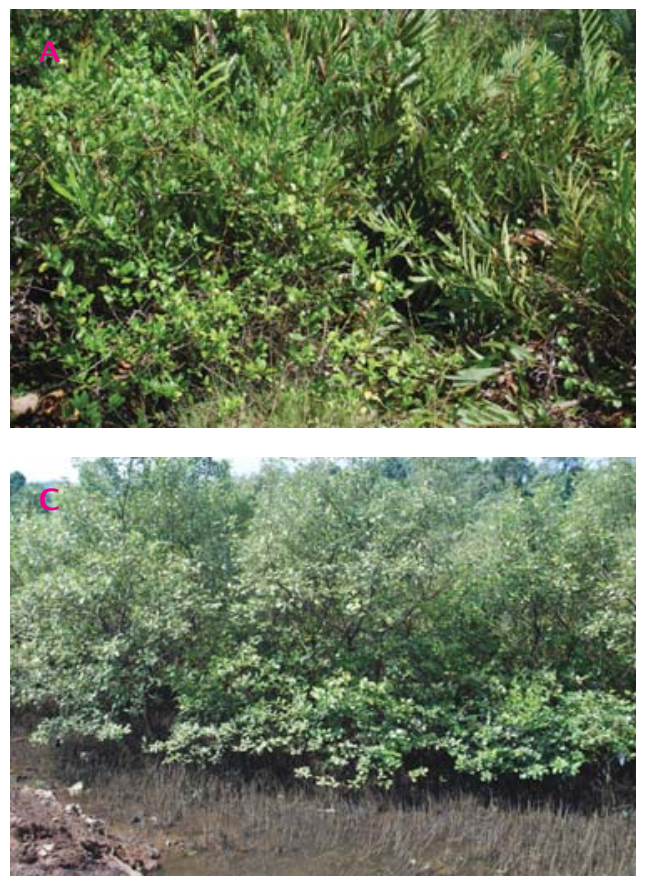

sebelumnya dikenal dengan Total Actual Acidity) (McElnea \& Ahern, 2004a), TSA (Titratable Sulfidic Acidity atau sebelumnya dikenal dengan Total Sulfidic Acidity) (TPA-TAA) (McElnea \& Ahern, 2004b), pirit (Ahern et al., 1998a; 1998b), karbon organik dengan metode Walkley \& Black (Sulaeman et al., 2005), N-total dengan metode Kjedhal (Sulaeman et al., 2005), $\mathrm{PO}_{4}$ dengan metode Bray 1 (Sulaeman et al., 2005), Fe dengan spektrofotometer (Sulaeman et al., 2005), Al dengan spektrofotometer (Sulaeman et al., 2005), dan tekstur dengan metode hidrometer (Abdurachman et al., 2006). Ukuran kematangan tanah ditentukan dengan mengetahui nilai $\mathrm{n}$ tanah yang dihitung dengan menggunakan rumus (Pons \& Zonneveld, 1965):

$$
n=\frac{A-0.2 R}{L+3 H}
$$

di mana:

$\mathrm{n}$ : Ukuran kematangan tanah

A : Persentase kandungan air dalam tanah pada
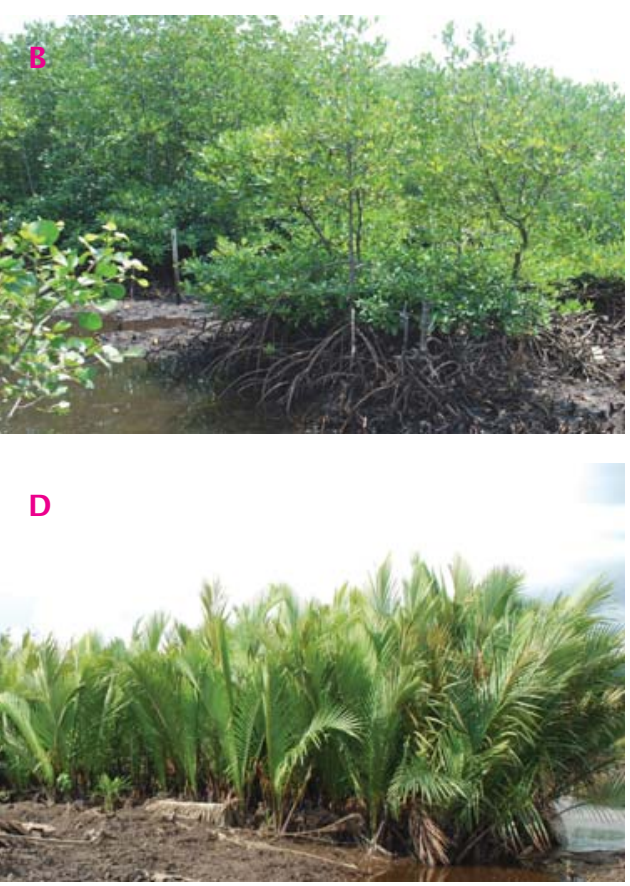

Gambar 1. Jenis vegetasi mangrove di mana dilakukan pengukuran dan pengambilan contoh tanah (A: paku laut; B: bakau; C: api-api; D: nipah)

Figure 1. Species of mangrove where soil measurement and sampling were carried out (A: Acrostichum aureum; B: Rhizophora apiculata; C: Avicennia alba; D: Nypa fruticans) 


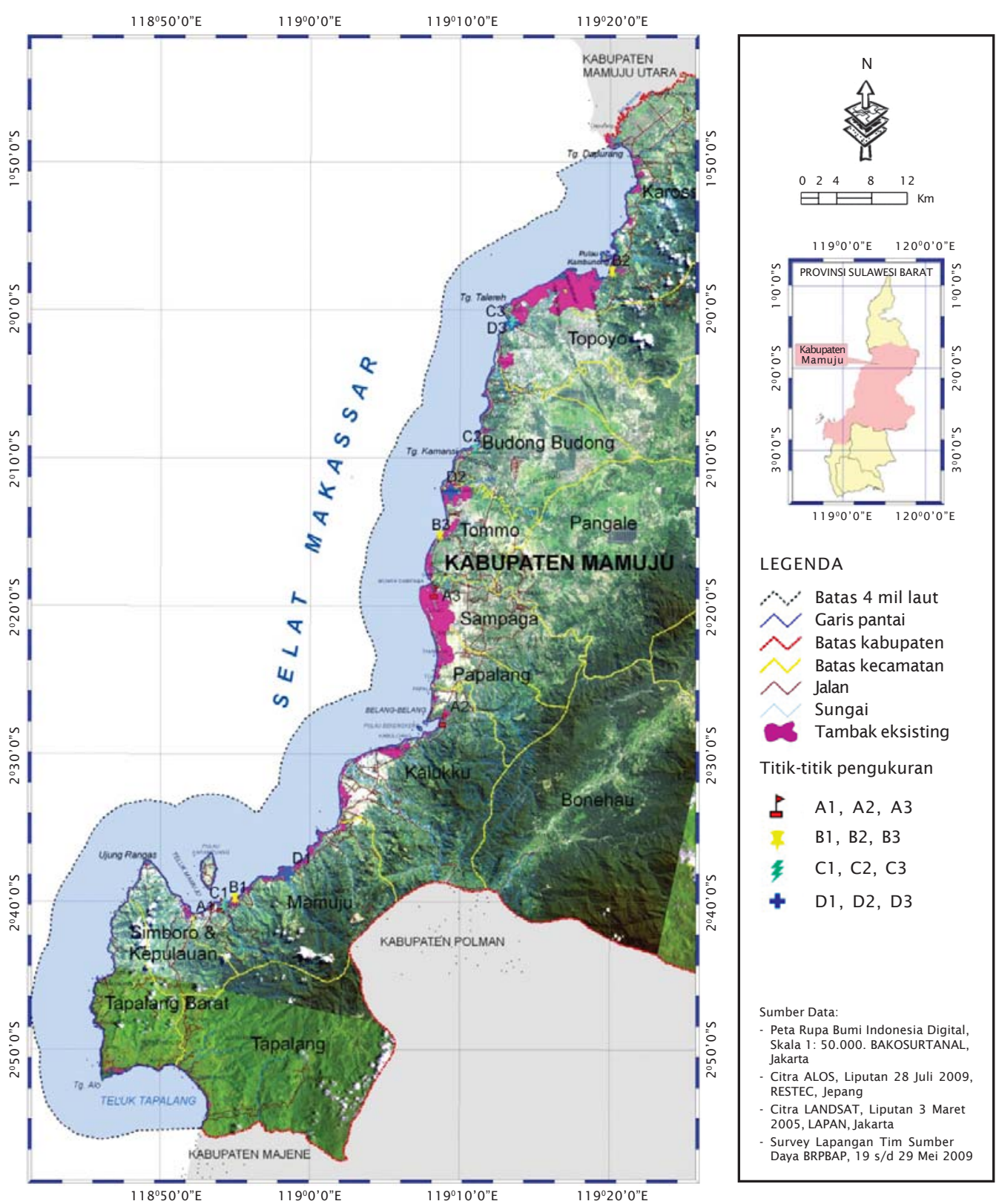

Gambar 2. Titik-titik pengukuran dan pengambilan contoh tanah di hutan mangrove Kabupaten Mamuju Provinsi Sulawesi Barat (A: paku laut; B: bakau; C: api-api; D: nipah)

Figure 2. Sampling points of soil measurement and soil collection on mangrove forest of Mamuju Regency, West Sulawesi Province (A: Acrostichum aureum; B: Rhizophora apiculata; C: Avicennia alba; D: Nypa fruticans) 
kondisi lapangan

$\mathrm{R}$ : Persentase debu + pasir dalam tanah

$\mathrm{L}$ : Persentase liat dalam tanah

$\mathrm{H}$ : Persentase kandungan bahan organik dalam tanah

Nilai-nilai kuantitatif peubah kualitas tanah dari setiap jenis vegetasi mangrove dan kedalaman tanah berbeda ditampilkan dalam bentuk rata-rata \pm standar deviasi. Homogenitas data dievaluasi dengan Uji Levene. Data yang tidak homogen ditransformasi terlebih dahulu sebelum dianalisis lebih lanjut. Analisis ragam digunakan untuk menguji perbedaan karakteristik tanah dari jenis vegetasi mangrove berbeda, sedangkan Uji T untuk dua contoh bebas dari kedalaman tanah berbeda digunakan untuk menguji perbedaan karakteristik tanah pada dua kedalaman tanah pada jenis vegetasi yang sama. Peubah kualitas tanah yang berbeda nyata antar vegetasi diuji lanjut dengan Beda Nyata Jujur Tukey. Tingkat signifikansi ditetapkan pada taraf 10\%. Seluruh data dianalisis dengan bantuan Program Statistical Product and Service Solution (SPSS) versi 1 5,0 (SPSS, 2006).

\section{HASIL DAN BAHASAN}

\section{Vegetasi Mangrove}

Hasil pengamatan awal didapatkan adanya tegakan murni vegetasi api-api (Avicennia alba), bakau (Rhizophora apiculata), dan nipah (Nypa fruticans) di kawasan hutan mangrove Kabupaten Mamuju yang menjadi titik-titik pengukuran dan pengambilan contoh tanah dalam penelitian ini. Vegetasi tersebut juga telah dijumpai di pantai Lariang (sekarang termasuk Kecamatan Karossa, Kabupaten Mamuju, dan Kabupaten Mamuju Utara) (ADB,
1997). Menurut Tomlinson, 1986 dalam Hogart, 2007, bahwa Avicennia, Rhizophora, Bruguiera, Ceriops, Kandelia, Sonneratia, Lumnitzera, Laguncularia, dan Nypa adalah flora mangrove mayor atau flora mangrove yang sebenarnya yaitu flora yang menunjukkan kesetiaan terhadap habitat mangrove yang mempunyai kemampuan membentuk tegakan murni dan secara dominan mencirikan struktur komunitas, secara morfologi mempunyai bentuk adaptif khusus terhadap lingkungan dan mempunyai mekanisme fisiologis dalam mengontrol salinitas. Hasil klasifikasi vegetasi mangrove menunjukkan bahwa spesies vegetasi itu tergolong dalam genus maupun famili yang berbeda seperti terlihat pada Tabel 1. Oleh karena itu, diharapkan adanya perbedaan genus maupun famili dari vegetasi tersebut juga mengindikasikan bahwa vegetasi tersebut tumbuh pada tanah dengan karakteristik yang berbeda pula. Di Kabupaten Mamuju, vegetasi api-api ditemukan tumbuh di tepi pantai dan ke arah darat dijumpai vegetasi bakau, sedangkan vegetasi nipah dijumpai tumbuh di daerah transisi antara hutan mangrove dan hutan daratan dan sekitar pinggir sungai yang memiliki sumber air tawar. Hal ini menunjukkan bahwa hutan mangrove selalu bersifat suksesi yang mengalami perubahan yang bertahap ke arah komunitas yang non-halopitik (tidak menyukai garam). Vegetasi paku laut (Acrostichum aureum) ditemukan tumbuh di daerah yang dulunya didominasi oleh vegetasi mangrove (vegetasi campuran) yang kemudian ditebang dan ditelantarkan. Dikatakan oleh Noor (2004) bahwa beberapa vegetasi seperti paku laut (Acrostichum aureum), galam (Melaleuca leucadendron), dan purun (Eleocharis dulcis) menempati daerah yang

Tabel 1. Famili dan genus vegetasi mangrove di mana dilakukan pengukuran dan pengambilan contoh tanah di kawasan hutan mangrove Kabupaten Mamuju Provinsi Sulawesi Barat

Table 1. Family and genera of mangrove where soil measurement and sampling were conducted in Mamuju Regency West Sulawesi Province

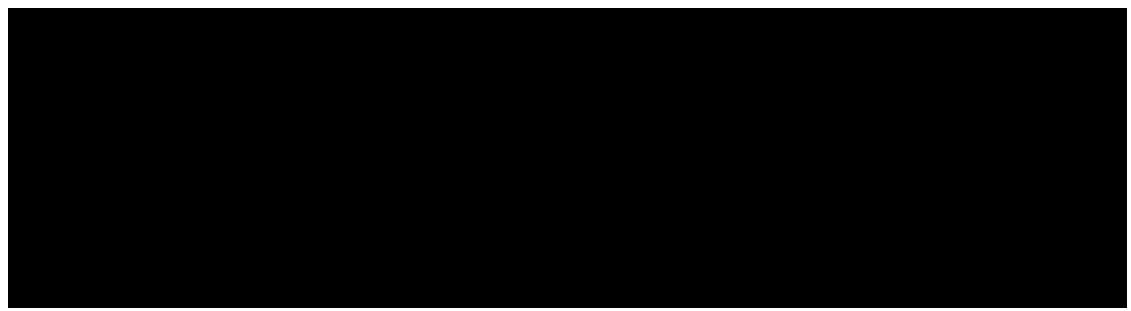


sudah terbuka atau terbakar. Paku laut tergolong flora mangrove minor, yakni flora mangrove yang tidak mampu membentuk tegakan murni, sehingga secara morfologis tidak berperan dominan dalam struktur komunitas hutan mangrove (Tomlinson, 1986 dalam Hogart, 2007).

\section{Klasifikasi Tanah}

Berdasarkan pada Taksonomi Tanah (Soil Survey Staff, 2001), tanah di bawah tegakan vegetasi mangrove di Kabupaten Mamuju diklasifikasikan sebagai Sulfaquent dan Sulfihemits untuk kategori Kelompok Besar (Great Groups). Sulfaquent dicirikan dengan Aquents yang mempunyai bahan sulfidik atau pirit sampai 0,5 m dari permukaan tanah dan termasuk tanah sulfat masam potensial. Dalam kategori Kelompok Inti (Ordo), Sulfaquent dimasukkan dalam Entisol atau pada sistem Klasifikasi Tanah dari Pusat Penelitian Tanah dimasukkan dalam tanah Aluvial. Tanah sulfat masam tidak hanya didapatkan dalam tanah mineral, tetapi juga dalam tanah organik, termasuk tanah sulfat masam di Kabupaten Mamuju yang diklasifikasi sebagai Sulfihemits. Sulfihemits dicirikan dengan keberadaan bahan sulfidik sampai 1,0 m dari permukaan yang tidak teroksidasi dan tidak mempunyai horizon sulfurik pada kedalaman $0,5 \mathrm{~m}$ dari permukaan tanah serta juga digolongkan sebagai tanah sulfat masam potensial. Dalam kategori Kelompok Inti, Sulfihemits adalah Histosol atau pada sistem Klasifikasi Tanah dari Pusat Penelitian Tanah dimasukkan dalam Organosol.

\section{Kualitas Tanah}

Potensial redoks tanah menunjukkan status tanah yang teroksidasi atau tereduksi. Potensial redoks adalah hasil pengukuran kuantitatif untuk menginformasikan suatu indeks diagnostik dari tingkat anaerobik atau anoksia tanah (Patrick \& Delaune, 1977). Potensial redoks adalah salah satu peubah penting dalam mengontrol persistensi berbagai senyawa organik dan anorganik tanah (Zhang et al., 2009). Pengukuran kualitas tanah di bawah tegakan vegetasi mangrove dilakukan dalam kondisi tanah yang tergenang, sebagai akibatnya potensial redoks tanah bernilai negatif baik pada kedalaman $0-0,25$ maupun 0,50-0,75 m (Tabel 2, 3, 4, 5, 6, 7). Potensial redoks tanah yang bernilai negatif menunjukkan bahwa tanah dalam kondisi tereduksi. Pada kedalaman 0-0,25 m; potensial redoks terendah $(-126 \mathrm{mV})$ dijumpai pada tanah vegetasi api-api, walaupun berbeda tidak nyata dengan vegetasi lainnya. Seperti disebutkan sebelumnya bahwa vegetasi apiapi ditemukan tumbuh dekat laut yang berarti vegetasi ini lebih lama tergenang air dan juga lebih banyak frekuensi penggenangannya daripada vegetasi lainnya. Dikatakan oleh Bengen (2001) bahwa Avicennia marina, Avicennia alba, dan Sonneratia griffithil menempati daerah yang terendam 10-19 kali/ bulan, sedangkan Rhizophora apiculata hanya terendam beberapa kali dalam setahun. Potensial redoks tanah menentukan zonasi hutan mangrove (Matthijs et al., 1999). Rendahnya potensial redoks tanah pada kedalaman 0,50-0,75 m pada semua jenis vegetasi sebagai akibat tanah yang jenuh air pada kedalaman tersebut.

$\mathrm{pH}_{\mathrm{F}}$ dapat digunakan untuk indikator secara cepat keberadaan dan kepelikan tanah sulfat masam aktual. $\mathrm{pH}_{\mathrm{F}}$ tanah pada semua jenis vegetasi mangrove lebih besar dari 5,5. Walaupun tanah sulfat masam, tetapi dalam kondisi tereduksi, maka pH tanah masih relatif tinggi. $\mathrm{pH}_{\mathrm{F}}$ tanah yang tertinggi dijumpai pada tanah vegetasi bakau, baik pada kedalaman 0-0,25 m maupun 0,50-0,75 m. Pada semua jenis vegetasi, $\mathrm{pH}_{\mathrm{F}}$ tanah lebih tinggi pada kedalaman 0-0,25 m daripada 0,50-0,75 m, walaupun berbeda tidak nyata, sebagai akibat proses remediasi alami yang berlangsung dalam waktu yang sangat lama yang menyebabkan terbilasnya senyawa atau unsur penyebab kemasaman tanah pada kedalaman 0-0,25 m. Namun demikian, pengukuran kemasaman tanah dengan $\mathrm{pH}$-meter harus dilaksanakan dalam kondisi contoh basah untuk mencegah oksidasi pirit (senyawa yang umum dalam tanah mangrove) menjadi asam sulfat yang dapat menyebabkan penurunan nilai $\mathrm{pH}$ yang besar dibandingkan dengan yang normal jika diukur secara in situ (English et al., 1997).

Berbeda dengan hasil pengukuran $\mathrm{pH}_{\mathrm{F}}$ adalah hasil pengukuran $\mathrm{pH}_{\text {FOx }}$ yaitu $\mathrm{pH}$ yang diukur di lapangan setelah tanah diberikan $\mathrm{H}_{2} \mathrm{O}_{2} 30 \%$. Pemberian $\mathrm{H}_{2} \mathrm{O}_{2} 30 \%$ dalam pengukuran $\mathrm{pH}_{\mathrm{FOX}}$ dimaksudkan agar potensi kemasaman yang ada dalam tanah dapat teroksidasi seluruhnya secara paksa. Sebagai akibatnya $\mathrm{pH}_{\mathrm{FOx}}$ yang terukur menjadi lebih rendah daripada hasil pengukuran $\mathrm{pH}_{\mathrm{F}}$. Salinitas dan alkalinitas air yang ada tidak dapat 


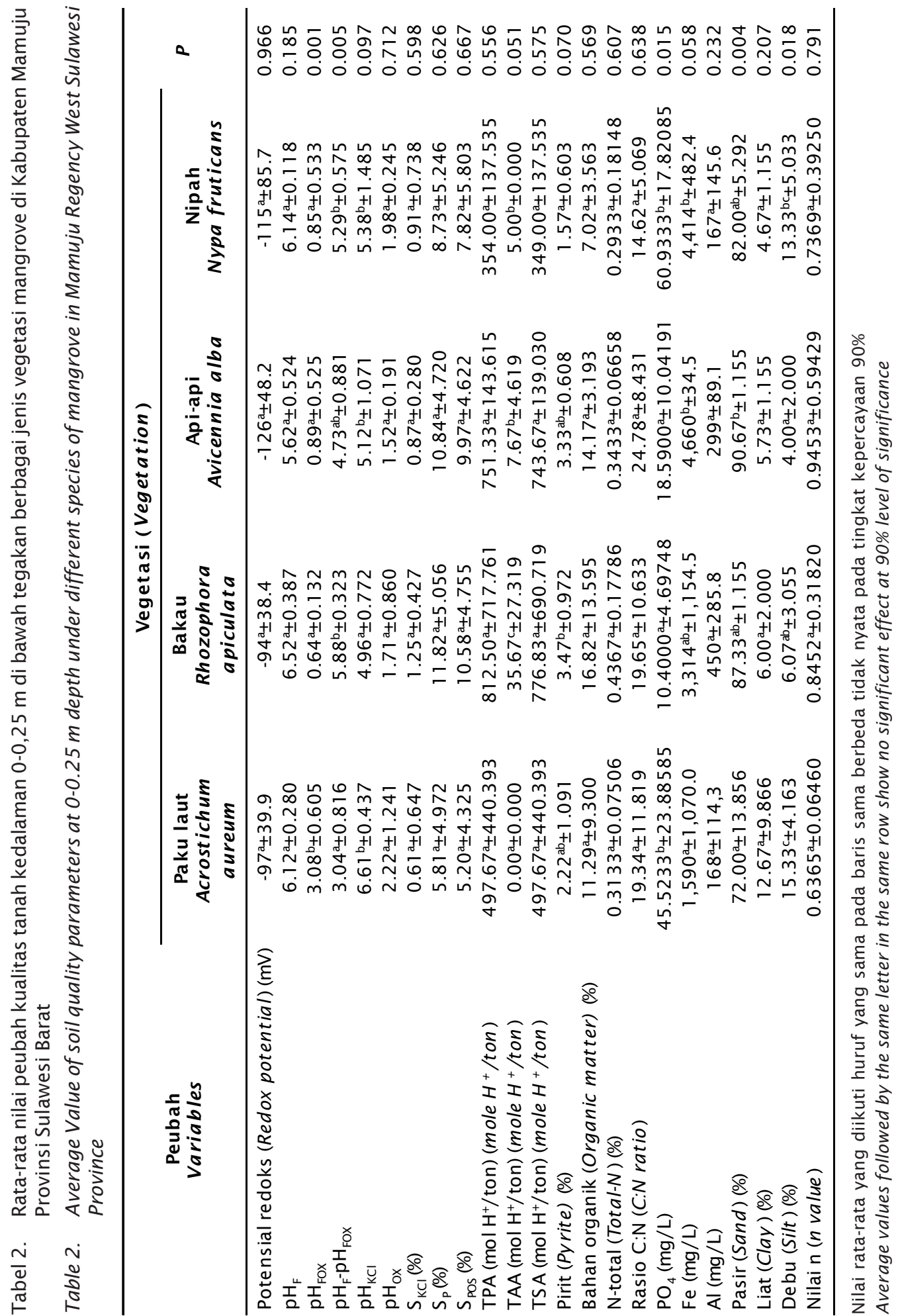


menetralisir potensial kemasaman sehingga $\mathrm{pH}_{\mathrm{FOX}}$ tetap menjadi rendah. $\mathrm{pH}_{\mathrm{FOX}}$ tanah tertinggi dijumpai pada tanah vegetasi paku laut yang berbeda nyata dengan tanah vegetasi bakau, api-api, dan nipah pada kedua kedalaman tanah (Tabel 2 dan 3). Sebagai akibat dari $\mathrm{pH}_{\mathrm{F}}$ yang tidak terlalu jauh berbeda pada semua vegetasi dan $\mathrm{pH}_{\mathrm{FOx}}$ yang tinggi pada tanah vegetasi paku laut, menyebabkan $\mathrm{pH}_{\mathrm{F}}-\mathrm{pH}_{\mathrm{FOX}}$ menjadi rendah pada tanah vegetasi tersebut. Nilai $\mathrm{pH}_{\mathrm{F}}-\mathrm{pH}_{\mathrm{FOX}}$ dapat digunakan sebagai indikator besarnya nilai potensi kemasaman pada tanah sulfat masam. Oleh karena itu, tanah vegetasi paku laut memiliki potensi kemasaman yang terendah, sedangkan vegetasi bakau memiliki potensi kemasaman tanah yang paling tinggi. Paku laut adalah vegetasi yang menempati tanah terbuka dan pernah terbakar (Noor, 2004), sehingga diduga dengan kondisi demikian maka potensi kemasaman telah banyak terbuang secara alami untuk waktu yang cukup lama. Tanah di bawah tegakan vegetasi Rhizophorasp. mengandung material serat akar yang tinggi dari vegetasi tersebut yang dapat menjadi sangat masam dan meracuni tanaman apabila teroksidasi (Jordan, 1964). Juga telah dilaporkan oleh Ukpong (1995) bahwa tanah vegetasi Rhizophora sp. memiliki pH kering udara 2,9-3,8 yang lebih rendah daripada tanah vegetasi Avicennia africana yang memiliki $\mathrm{pH}$ kering udara 4,3-4,9 di hutan mangrove Nigeria Tenggara. Kemungkinan lain lebih rendahnya $\mathrm{pH}$ yang diukur di laboratorium dari tanah vegetasi mangrove tertentu sebab adanya kandungan tanin yang tinggi dari Rhizophora sp., Bruguiera sp., Ceriops tagal, Xylocarpus granatum, dan Nypa fruticans yang dapat menyebabkan tanah lebih masam (Sunarto, 2008).

Pada Tabel 2 dan 3 terlihat adanya kecenderungan pola nilai $\mathrm{pH}_{\text {Fox }}$ yang relatif sama dengan $\mathrm{pH}_{\mathrm{KCl}}(\mathrm{pH}$ dengan pengekstrak $1 \mathrm{~N} \mathrm{KCl})$ dan $\mathrm{pH}_{\mathrm{Ox}}(\mathrm{pH}$ dengan pengekstrak $1 \mathrm{~N} \mathrm{KCl}$ yang selanjutnya dioksidasi dengan $\mathrm{H}_{2} \mathrm{O}_{2}$ ) pada kedua kedalaman tanah. $\mathrm{pH}_{\mathrm{KCl}}$ yang tertinggi juga dijumpai pada tanah vegetasi paku laut yang berbeda nyata dengan tanah vegetasi bakau. Pengukuran $\mathrm{pH}_{\mathrm{KCI}}$ menunjukkan nilai $\mathrm{pH}$ tanah setelah $\mathrm{H}^{+}$dalam kompleks jerapan didesak keluar dan masuk ke dalam larutan tanah oleh kation lain sehingga disebut pula $\mathrm{pH}$ tanah potensial. $\mathrm{pH}_{\mathrm{KCl}}$ biasanya diukur untuk membandingkan $\mathrm{pH}$ yang menggunakan pengekstrak $\mathrm{H}_{2} \mathrm{O}$ $\left(\mathrm{pH}_{\mathrm{H} 2 \mathrm{O}}\right)$. Walaupun dalam penelitian ini tidak dilakukan pengukuran $\mathrm{pH}_{\mathrm{H} 2 \mathrm{O}}(\mathrm{pH}$ dengan pengekstrak $\mathrm{H}_{2} \mathrm{O}$ ) tanah, tetapi data dari tanah sulfat masam menunjukkan bahwa $\mathrm{pH}_{\mathrm{KCl}}$ lebih rendah daripada $\mathrm{pH}_{\mathrm{H} 2 \mathrm{O}}\left(\mathrm{pH}_{\mathrm{H} 2 \mathrm{O}}=5,69 \pm 1,067\right.$; $\mathrm{pH}_{\mathrm{KCl}}=5,17 \pm 1,065 ; \mathrm{n}=12$ (tidak dipublikasi, 2009)). Apabila $\mathrm{pH}_{\mathrm{KCl}}$ lebih rendah 0,5 unit atau lebih daripada $\mathrm{pH}_{\mathrm{H} 2 \mathrm{O}}$, menunjukkan bahwa sejumlah Al dapat tukar ditemukan dalam tanah tersebut. Menurunnya $\mathrm{pH}$ dengan pengekstrak KCl adalah sebagai akibat hidrolisis dari Al diganti oleh K (Hardjowigeno, 2003). Kandungan Al yang rendah pada vegetasi paku laut berdampak pada $\mathrm{pH}_{\mathrm{KCl}}$ yang tinggi.

Pada tanah sulfat masam yang dicirikan dengan kandungan pirit, maka salah satu sumber kemasamannya adalah sulfur. Pirit yang teroksidasi akan menghasilkan asam sulfat dan ferrosulfat yang apabila bereaksi dengan air melepaskan ferrisulfat yang selanjutnya apabila teroksidasi kembali akan menghasilkan asam sulfat. Hasil analisis sulfur $\left(\mathrm{S}_{\mathrm{KCI}}, \mathrm{S}_{\mathrm{P}}, \mathrm{S}_{\mathrm{POS}}\right)$ yang diekstrak dengan pengekstrak yang berbeda menunjukkan bahwa kandungan sulfur terendah dijumpai pada tanah vegetasi paku laut, walaupun berbeda tidak nyata dengan tanah vegetasi lainnya (Tabel 2 dan 3). Hasil ini juga mendukung hasil pengukuran berbagai $\mathrm{pH}$ seperti $\mathrm{pH}_{\mathrm{F}}, \mathrm{pH}_{\mathrm{FOX}}, \mathrm{pH}_{\mathrm{KCl}}$, dan $\mathrm{pH}_{\mathrm{OX}}$ di mana $\mathrm{pH}$ tanah vegetasi paku laut lebih tinggi daripada vegetasi lainnya. Sebagai sumber kemasaman yang penting pada tanah sulfat masam, maka sulfur yang diukur dalam bentuk $\mathrm{S}_{\mathrm{POS}}$ tanah telah digunakan oleh Ahern et al. (1998b) untuk menentukan kebutuhan kapur bagi tanah sulfat masam.

Hasil pengukuran peubah lain yang menggambarkan kemasaman tanah yaitu TPA, TAA, dan TSA menunjukkan kecenderungan pola yang sama dengan peubah kemasaman tanah lainnya seperti $\mathrm{pH}_{\mathrm{F}}-\mathrm{pH}_{\mathrm{FOX}}, \mathrm{S}_{\mathrm{KCl}}, \mathrm{S}_{\mathrm{p}}, \mathrm{S}_{\mathrm{POS}}$. Dari Tabel 2 dan 3 terlihat bahwa nilai TPA, TAA, dan TSA tertinggi dijumpai pada tanah vegetasi bakau dan hasil ini mendukung pernyataan sebelumnya bahwa tanah vegetasi bakau memiliki potensi kemasaman yang tinggi seperti terlihat pada nilai $\mathrm{pH}_{\mathrm{F}}-\mathrm{pH}_{\mathrm{FOx}}$. Telah dikatakan oleh McElnea et al. (2002a; 2002b) bahwa pada tanah sulfat masam yang rendah kandungan bahan organiknya, maka TSA berkorelasi baik dengan $S_{\text {pos. }}$. TSA juga mempunyai hubungan secara liniar dengan kandungan pirit (Sutrisno, 1990 dalam Noor, 2004) pada tanah sulfat masam.

Pirit adalah ciri utama dari tanah sulfat masam. Kandungan pirit berbeda nyata pada 


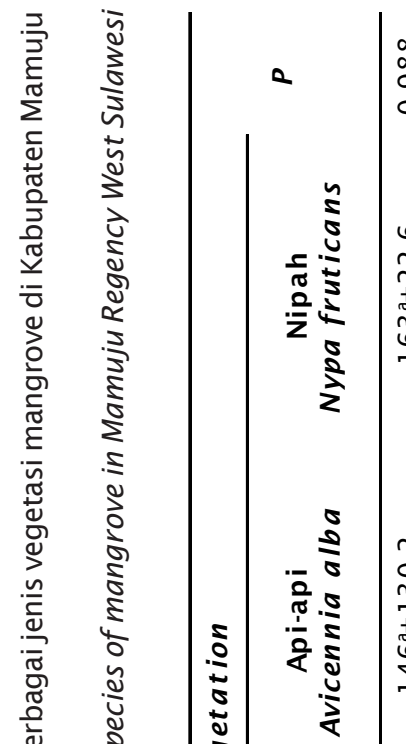

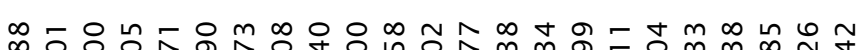

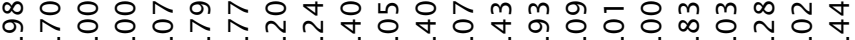

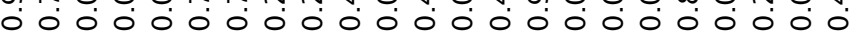

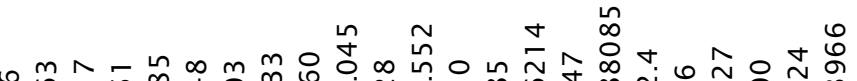
N-

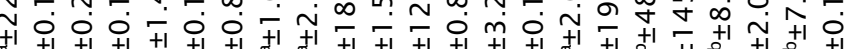

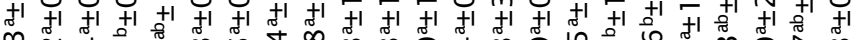

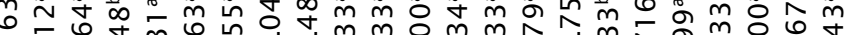

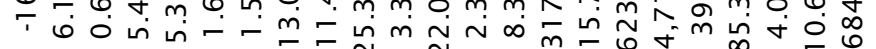
in ñ 0 in

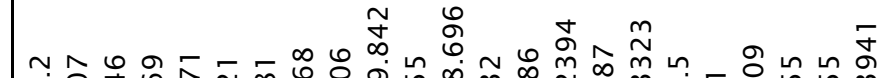

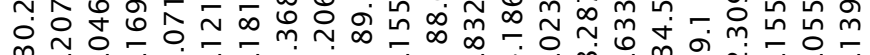

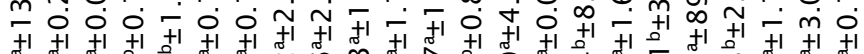
○人

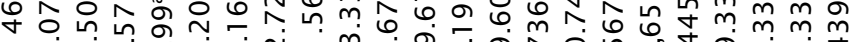

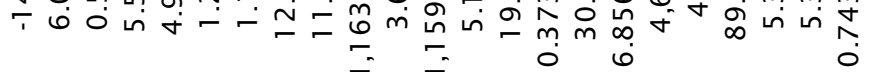

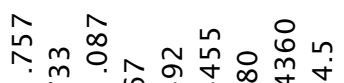

. 万人

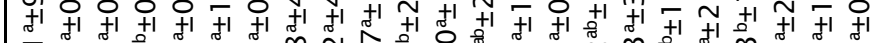
б †

$\circ \stackrel{m}{m} \stackrel{m}{\infty} \stackrel{\infty}{\infty}$ $\circ$

$\infty$ 人 .

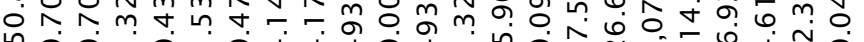

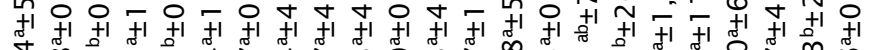
丈 - 
Tabel 4. Rata-rata nilai peubah kualitas tanah di bawah tegakan paku laut pada kedalaman berbeda di Kabupaten Mamuju Provinsi Sulawesi Barat

Table 4. Average value of soil quality parameters under Acrosthicum aureum vegetation at different soil depths in Mamuju Regency West Sulawesi Province

\begin{tabular}{|c|c|c|c|}
\hline \multirow{2}{*}{$\begin{array}{l}\text { Peubah } \\
\text { Variable }\end{array}$} & \multicolumn{2}{|c|}{$\begin{array}{l}\text { Kedalaman } \\
\text { Depth }(\mathrm{m})\end{array}$} & \multirow[t]{2}{*}{$P$} \\
\hline & $0-0,25$ & $0,50-0,75$ & \\
\hline Potensial redoks (Redox potential) (mV) & $-97 \pm 39.9$ & $-144 \pm 50.2$ & 0.869 \\
\hline $\mathrm{pH}_{\mathrm{F}}$ & $6.12 \pm 0.280$ & $5.98 \pm 0.707$ & 0.776 \\
\hline $\mathrm{pH}_{\mathrm{FOX}}$ & $3.08 \pm 0.605$ & $3.11 \pm 0.706$ & 0.720 \\
\hline $\mathrm{pH}_{\mathrm{F}}-\mathrm{pH}_{\mathrm{FOX}}$ & $3.04 \pm 0.816$ & $3.11 \pm 1.326$ & 0.939 \\
\hline $\mathrm{pH}_{\mathrm{KCl}}$ & $6.61 \pm 0.437$ & $6.61 \pm 0.615$ & 1.000 \\
\hline $\mathrm{pH}_{\mathrm{Ox}}$ & $2.22 \pm 1.241$ & $2.14 \pm 1.538$ & 0.947 \\
\hline $\mathrm{S}_{\mathrm{KCl}}(\%)$ & $0.61 \pm 0.347$ & $0.77 \pm 0.479$ & 0.828 \\
\hline$S_{p}(\%)$ & $5.81 \pm 1.972$ & $5.84 \pm 1.149$ & 0.977 \\
\hline $\mathrm{S}_{\mathrm{POS}}(\%)$ & $5.20 \pm 1.325$ & $5.07 \pm 1.174$ & 0.982 \\
\hline TPA $\left(\right.$ mol H${ }^{+} /$ton $)\left(\right.$mole $\mathrm{H}^{+} /$ton $)$ & $497.67 \pm 440.393$ & $552.33 \pm 493.330$ & 0.893 \\
\hline $\mathrm{TAA}\left(\mathrm{mol} \mathrm{H}^{+} /\right.$ton $)\left(\right.$mole $\mathrm{H}^{+} /$ton $)$ & 0 & 0 & 1.000 \\
\hline $\mathrm{TSA}\left(\mathrm{mol} \mathrm{H}^{+} /\right.$ton $)\left(\right.$mole $\mathrm{H}^{+} /$ton $)$ & $497.67 \pm 440.393$ & $552.33 \pm 493.330$ & 0.893 \\
\hline Pirit (Pyrite) (\%) & $2.22 \pm 1.091$ & $2.47 \pm 0.203$ & 0.870 \\
\hline Bahan organik (Organic matter) (\%) & $11.29 \pm 9.300$ & $11.88 \pm 5.900$ & 0.931 \\
\hline $\mathrm{N}$-total $($ Total-N) (\%) & $0.3155 \pm 0.07330$ & $0.2985 \pm 0.09003$ & 0.812 \\
\hline Rasio C:N (C:N ratio) & $19.34 \pm 11.819$ & $23.01 \pm 7.527$ & 0.674 \\
\hline $\mathrm{PO}_{4}(\mathrm{mg} / \mathrm{L})$ & $45.5233 \pm 23.88585$ & $52.0933 \pm 26.66185$ & 0.766 \\
\hline $\mathrm{Fe}(\mathrm{mg} / \mathrm{L})$ & $1,590 \pm 1,070.0$ & $1,787 \pm 1,563.7$ & 0.866 \\
\hline $\mathrm{Al}(\mathrm{mg} / \mathrm{L})$ & $168 \pm 114.3$ & $231 \pm 129.7$ & 0.889 \\
\hline Pasir (Sand) (\%) & $72.00 \pm 13.856$ & $74.00 \pm 6.928$ & 0.834 \\
\hline Liat (Clay) (\%) & $12.67 \pm 9.866$ & $8.67 \pm 4.619$ & 0.559 \\
\hline Debu (Silt) (\%) & $15.33 \pm 4.163$ & $17.33 \pm 2.309$ & 0.507 \\
\hline Nilai $\mathrm{n}$ ( $n$ value) & $0.9453 \pm 0.59429$ & $0.5896 \pm 0.04210$ & 0.360 \\
\hline
\end{tabular}

vegetasi tanah tertentu. Kandungan pirit yang rendah didapatkan pada vegetasi nipah namun berbeda tidak nyata dengan tanah vegetasi paku laut. Kandungan pirit yang tinggi didapatkan pada vegetasi bakau dan api-api. Faktor-faktor yang mempengaruhi pembentukan pirit adalah jumlah bahan organik, suhu sedimen, pasokan $\mathrm{SO}_{4}$ dan bikarbonat, serta suasana anaerob dan kandungan Fe (Dent, 1986). Tingginya kandungan pirit tanah vegetasi bakau dan api-api diduga sebagai akibat keberadaannya yang lebih dekat ke arah laut sehingga pasokan sulfat dari air laut cukup tinggi. Selain itu, tanah di kedua vegetasi tersebut memiliki kandungan bahan organik yang lebih tinggi (Tabel 2 dan 3) yang merupakan sumber karbon bagi bakteri dalam pembentukan pirit. Suasana anaerob merupakan kondisi yang lebih umum pada vegetasi bakau dan api-api, sebab berada pada daerah yang lebih dekat ke laut dan vegetasi ini lebih lama tergenang. Selanjutnya Noor (2004) menyatakan bahwa endapan liat yang berasal dari serat sisa akar vegetasi bakau mengandung pirit yang tinggi.

Berdasarkan uraian mengenai peubahpeubah kemasaman tanah menunjukkan bahwa hasil pengukuran $\mathrm{pH}_{\mathrm{F}}$ relatif sama pada berbagai vegetasi mangrove dan hasil pengukurannya juga relatif tinggi. Hasil pengukuran $\mathrm{pH}$ lain $\left(\mathrm{pH}_{\mathrm{FOX}}, \mathrm{pH}_{\mathrm{KCl}}, \mathrm{pH}_{\mathrm{OX}}\right)$ yang kesemuanya menggunakan larutan pengekstrak yang berfungsi untuk mengoksidasi potensi kemasaman tanah, menunjukkan hasil pengukuran yang lebih rendah. Seperti dikatakan oleh Subagyo (2006), bahwa pH tanah di lapangan terukur lebih tinggi dibandingkan dengan yang terukur di 
laboratorium yang menunjukkan bahwa kondisi $\mathrm{pH}$ lapangan (basah) dalam suasana reduktif berbeda dengan $\mathrm{pH}$ laboratorium (kering) dalam suasana oksidatif. Pada tanah vegetasi api-api yang mememiliki potensi kemasaman yang rendah, pada pengukuran $\left(\mathrm{pH}_{\mathrm{FOX}}, \mathrm{pH}_{\mathrm{KCl}}, \mathrm{pH}_{\mathrm{OX}}\right)$ terukur dengan nilai masingmasing lebih tinggi daripada vegetasi lainnya. Walaupun pengukuran $\mathrm{pH}_{\mathrm{F}}$ adalah suatu metode kualitatif, tetapi tidak dapat digunakan sebagai pengganti analisis di laboratorium dalam identifikasi tanah sulfat masam untuk penilaian berbagai tujuan, termasuk untuk evaluasi lahan untuk budidaya tambak. Oleh karena itu, hasil pengukuran $\mathrm{pH}_{\mathrm{F}}$ tidak dapat dijadikan acuan dalam menilai derajat kemasaman pada tanah sulfat masam, sebab pada saat teroksidasi maka tanah dapat berubah menjadi lebih masam. Di antara empat jenis vegetasi yang dikaji karakteristik tanahnya menunjukkan bahwa tanah vegetasi paku laut memiliki kualitas tanah yang lebih baik dalam hal derajat kemasaman tanah untuk budidaya tambak. Secara umum, tanah vegetasi paku laut memiliki pH yang lebih tinggi dan potensi kemasaman yang rendah serta kandungan pirit yang rendah dibandingkan dengan vegetasi lainnya (bakau, apiapi, nipah).

Daun mangrove yang telah gugur dirombak oleh mikroorganisme seperti jamur, bakteri, dan protozoa, sehingga hutan mangrove mampu memproduksi sejumlah besar bahan organik. Daun yang gugur adalah penyumbang terbesar bahan organik di sedimen hutan mangrove (Koch, 2005). Seperti telah disebutkan sebelumnya bahwa kandungan bahan organik yang tinggi dijumpai pada tanah vegetasi

Tabel 5. Rata-rata nilai peubah kualitas tanah di bawah tegakan bakau pada kedalaman berbeda di Kabupaten Mamuju Provinsi Sulawesi Barat

Table 5. Average value of soil quality parameters under Rhizophora mucronata vegetation at different soil depths in Mamuju Regency West Sulawesi Province

\begin{tabular}{|c|c|c|c|}
\hline \multirow{2}{*}{$\begin{array}{l}\text { Peubah } \\
\text { Variable }\end{array}$} & \multicolumn{2}{|c|}{$\begin{array}{c}\text { Kedalaman } \\
\text { Dept } h(m)\end{array}$} & \multirow[t]{2}{*}{$P$} \\
\hline & $0-0,25$ & $0,50-0,75$ & \\
\hline Potensial redoks (Redox potential) (mV) & $-94 \pm 38.4$ & $-161 \pm 91.3$ & 0.307 \\
\hline $\mathrm{pH}_{\mathrm{F}}$ & $6.52 \pm 0.387$ & $6.36 \pm 0.254$ & 0.567 \\
\hline $\mathrm{pH}_{\mathrm{FOX}}$ & $0.64 \pm 0.132$ & $0.70 \pm 0.356$ & 0.798 \\
\hline $\mathrm{pH}_{\mathrm{F}}-\mathrm{pH}_{\mathrm{FOX}}$ & $5.88 \pm 0.323$ & $5.66 \pm 0.362$ & 0.464 \\
\hline $\mathrm{pH}_{\mathrm{KCl}}$ & $4.96 \pm 0.772$ & $4.76 \pm 1.105$ & 0.813 \\
\hline $\mathrm{pH}_{\mathrm{Ox}}$ & $1.71 \pm 0.860$ & $1.75 \pm 1.292$ & 0.961 \\
\hline $\mathrm{S}_{\mathrm{KCl}}(\%)$ & $1.25 \pm 0.427$ & $1.56 \pm 0.517$ & 0.468 \\
\hline$S_{p}(\%)$ & $11.82 \pm 5.056$ & $12.88 \pm 4.543$ & 0.802 \\
\hline $\mathrm{S}_{\mathrm{POS}}(\%)$ & $10.58 \pm 4.755$ & $11.32 \pm 4.660$ & 0.856 \\
\hline TPA (mol H+ ton) $\left(\right.$ mole $\mathrm{H}^{+} /$ton $)$ & $812.50 \pm 717.761$ & $1,068.67 \pm 951.757$ & 0.729 \\
\hline $\mathrm{TAA}\left(\mathrm{mol} \mathrm{H}^{+} /\right.$ton $)\left(\right.$mole $\mathrm{H}^{+} /$ton $)$ & $35.67 \pm 27.319$ & $26.67 \pm 21.733$ & 0.678 \\
\hline $\mathrm{TSA}\left(\mathrm{mol} \mathrm{H}^{+} /\right.$ton $)\left(\right.$mole $\mathrm{H}^{+} /$ton $)$ & $776.83 \pm 690.719$ & $1,042.00 \pm 931.087$ & 0.712 \\
\hline Pirit (Pyrite) (\%) & $3.47 \pm 0.972$ & $4.65 \pm 1.096$ & 0.652 \\
\hline Bahan organik (Organic matter) (\%) & $16.82 \pm 13.596$ & $15.09 \pm 14.490$ & 0.887 \\
\hline N-total (Total-N) (\%) & $0.4384 \pm 0.17943$ & $0.3855 \pm 0.24455$ & 0.825 \\
\hline Rasio C:N (C:N ratio) & $19.65 \pm 10.633$ & $24.42 \pm 5.780$ & 0.532 \\
\hline $\mathrm{PO}_{4}(\mathrm{mg} / \mathrm{L})$ & $10.4000 \pm 4.69748$ & $10.9133 \pm 3.84360$ & 0.891 \\
\hline $\mathrm{Fe}(\mathrm{mg} / \mathrm{L})$ & $3,314 \pm 1,154.5$ & $4,559 \pm 121.2$ & 0.137 \\
\hline $\mathrm{Al}(\mathrm{mg} / \mathrm{L})$ & $430 \pm 285.8$ & $370 \pm 266.8$ & 0.741 \\
\hline Pasir (Sand) (\%) & $87.33 \pm 1.155$ & $87.33 \pm 1.155$ & 1.000 \\
\hline Liat (Clay) (\%) & $6.00 \pm 2.000$ & $6.00 \pm 2.000$ & 1.000 \\
\hline Debu (Silt) (\%) & $6.67 \pm 3.055$ & $6.67 \pm 1.155$ & 1.000 \\
\hline Nilai $\mathrm{n}$ ( $n$ value $)$ & $0.8452 \pm 0.31820$ & $0.9816 \pm 0.52766$ & 0.721 \\
\hline
\end{tabular}


bakau dan api-api. Hal ini terkait dengan kemungkinan produksi bahan organik yang tinggi di tanah vegetasi bakau dan api-api. Menurut Koch (2005), daun Rhizophora sp. dan Avicennia sp. mangandung karbon organik masing-masing $44,8 \pm 1,8 \%$ dan $39,5 \pm 2,8 \%$. Telah dilaporkan pula oleh Lacerda et al. (1995) bahwa kandungan bahan organik dan nitrogen tanah vegetasi api-api lebih tinggi daripada tanah vegetasi bakau, dan keduanya lebih tinggi daripada vegetasi mangrove lainnya di Brasil Tenggara. Selain itu, waktu penguraian kedua jenis vegetasi mangrove tersebut lebih cepat sehingga produksi bahan organiknya lebih tinggi. Daun Rhizophora apiculata terurai seluruhnya selama 132 hari dan lebih cepat daripada daun Bruguiera cylindrical, Sonneratia alba, dan Acanthus ilicifolius di hutan mangrove Teluk Ambon, Maluku (Sediadi \& Pramudji, 1987). Daun Avicennia marina di Selandia Baru terurai seluruhnya selama 6-8 minggu (Woodroffe, 1982).

Seperti halnya dengan kandungan bahan organik, maka kandungan $\mathrm{N}$-total tanah yang tinggi juga dijumpai pada tanah vegetasi bakau dan api-api. Bahan organik, selain sebagai sumber karbon, juga merupakan sumber nitrogen (Boyd, 2008). Oleh karena itu, kandungan $\mathrm{N}$-total yang tinggi juga dijumpai pada tanah vegetasi yang juga tinggi kandungan bahan organiknya. Telah dikatakan oleh Koch (2005) bahwa daun mangrove mengandung $\mathrm{N}$-total antara $1,2 \%$ dan 2,0\% dan bagian lainnya mengandung $0,24 \%$ dan $0,68 \%$.

Kandungan bahan organik yang tinggi pada vegetasi bakau dan api-api, tetapi tidak diikuti dengan kandungan $\mathrm{N}$ yang tinggi pula (walaupun bahan organik adalah sumber $\mathrm{N}$ ) juga menyebabkan lebih tingginya rasio $\mathrm{C}: \mathrm{N}$ tanah pada kedua vegetasi tersebut dibandingkan dengan vegetasi lainnya. Hasil analisis ragam menunjukkan bahwa rasio $\mathrm{C}: \mathrm{N}$ tanah berbeda tidak nyata antar vegetasi pada kedalaman 0-0,25 m, tetapi rasio C: $\mathrm{N}$ tanah vegetasi api-api lebih tinggi dan berbeda nyata dengan tanah nipah (Tabel 3). Secara umum, rasio $\mathrm{C}: \mathrm{N}$ tanah tergolong tinggi yaitu antara 14,62:1 dan 24,78:1 pada kedalaman 00,25 m dan antara 15,75:1 dan 30,47:1 pada kedalaman 0,50-0,75 m. Rasio C:N tanah yang ideal seharusnya 8:1 sampai 12:1 (Boyd, 2008). Walaupun rasio $\mathrm{C}: \mathrm{N}$ tergolong tinggi, tetapi masih lebih rendah daripada daripada rasio $\mathrm{C}: \mathrm{N}$ tanah gambut yang biasanya lebih besar dari
31:1 (Mustafa, 1998; Barchia, 2006). Pada tanah dengan rasio $\mathrm{C}: \mathrm{N}$ tinggi, maka terjadi immobilisasi $\mathrm{N}$ oleh mikrobiologi untuk memenuhi kebutuhan metabolismenya.

Kandungan fosfat tanah berbeda pada vegetasi yang berbeda, di mana kandungan fosfat yang tinggi dijumpai pada tanah vegetasi nipah dan paku laut dan berbeda nyata dengan kandungan fosfat pada tanah vegetasi bakau dan api-api. Kandungan fosfat yang rendah pada tanah vegetasi bakau dan api ini sebagai akibat dari $\mathrm{pH}$ tanah yang lebih rendah pada vegetasi tersebut. Pada tanah yang $\mathrm{pHnya}$ rendah, fosfat diikat secara kuat oleh Fe dan Al dalam bentuk $\mathrm{FePO}_{4}$ atau $\mathrm{AlPO}_{4}$ yang tidak larut (Barchia, 2006; Mustafa \& Sammut, 2007).

Kandungan Fe terendah dijumpai pada tanah vegetasi paku laut, namun berbeda tidak nyata dengan kandungan $\mathrm{Fe}$ pada tanah vegetasi bakau, tepai berbeda nyata dengan kandungan $\mathrm{Fe}$ tanah vegetasi api-api dan nipah. Seperti telah disebutkan sebelumnya bahwa kandungan pirit rendah dijumpai juga pada tanah vegetasi paku laut, sehingga diduga menjadi penyebab rendahnya kandungan $\mathrm{Fe}$ tanah. Fe adalah bagian dari pirit pada tanah sulfat masam yang dapat berasal dari sedimen.

Kandungan Al yang yang tinggi dijumpai pada tanah vegetasi bakau dan api-api, walaupun berbeda tidak nyata dengan tanah vegetasi lainnya. Hal ini diduga sebagai akibat $\mathrm{pH}$ tanah yang rendah pada vegetasi bakau dan api-api. Kandungan Al pada tanah sulfat masam meningkat pada $\mathrm{pH}$ yang lebih rendah, yaitu pH 4,0-4,5 (Dent, 1986). Selain itu, kandungan Al pada tanah sulfat masam berkaitan dengan oksidasi pirit. Suasana yang sangat masam mempercepat pelapukan mineral alumino-silikat akibat perusakan kisi dari mineral tipe 2:2 (seperti montmorillonit) menjadi mineral tipe 1:1 (kaolinit) dengan membebaskan dan melarutkan Al yang lebih banyak (Pons, 1973).

Telah diketahui bersama bahwa $\mathrm{pH}$ adalah pengontrol semua reaksi kimia, termasuk reaksi kimia dalam tanah. Nilai $\mathrm{pH}$ tanah dapat digunakan sebagai indikator kesuburan tanah kimiawi, karena dapat mencerminkan ketersediaan hara dalam tanah tersebut. Sebagai akibat dari $\mathrm{pH}$ tanah vegetasi paku laut lebih mendekati netral daripada vegetasi lainnya, maka ketersediaan unsur hara makro $(\mathrm{N}, \mathrm{P}, \mathrm{K})$ pada tanah vegetasi ini lebih besar. 
Tabel 6. Rata-rata nilai peubah kualitas tanah di bawah tegakan api-api pada kedalaman berbeda di Kabupaten Mamuju Provinsi Sulawesi Barat

Table 6. Average value of soil quality parameters under Avicennia alba vegetation at different soil depths in Mamuju Regency West Sulawesi Province

\begin{tabular}{|c|c|c|c|}
\hline \multirow{2}{*}{$\begin{array}{l}\text { Peubah } \\
\text { Variable }\end{array}$} & \multicolumn{2}{|c|}{$\begin{array}{l}\text { Kedalaman } \\
\text { Depth }(\mathrm{m})\end{array}$} & \multirow[t]{2}{*}{$P$} \\
\hline & $0-0,25$ & $0,50-0,75$ & \\
\hline Potensial redoks (Redox potential) (mV) & $-126 \pm 48.2$ & $-146 \pm 30.2$ & 0.270 \\
\hline $\mathrm{pH}_{\mathrm{F}}$ & $5.62 \pm 0.524$ & $6.07 \pm 0.202$ & 0.241 \\
\hline $\mathrm{pH}_{\mathrm{FOX}}$ & $0.89 \pm 0.525$ & $0.50 \pm 0.046$ & 0.269 \\
\hline $\mathrm{pH}_{\mathrm{F}}-\mathrm{pH}_{\mathrm{FOX}}$ & $4.73 \pm 0.881$ & $5.57 \pm 0.170$ & 0.181 \\
\hline $\mathrm{pH}_{\mathrm{KCl}}$ & $5.12 \pm 1.071$ & $4.99 \pm 0.744$ & 0.875 \\
\hline $\mathrm{pH}_{\mathrm{Ox}}$ & $1.52 \pm 0.191$ & $1.20 \pm 0.121$ & 0.069 \\
\hline $\mathrm{S}_{\mathrm{KCl}}(\%)$ & $0.87 \pm 0.280$ & $1.16 \pm 0.184$ & 0.212 \\
\hline$S_{p}(\%)$ & $10.84 \pm 4.720$ & $12.72 \pm 2.368$ & 0.572 \\
\hline $\mathrm{S}_{\mathrm{POS}}(\%)$ & $9.97 \pm 4.622$ & $11.56 \pm 2.206$ & 0.619 \\
\hline TPA (mol H+/ton) (mole $\mathrm{H}^{+} /$ton $)$ & $751.33 \pm 143.615$ & $1,163.33 \pm 189.843$ & 0.040 \\
\hline TAA $\left(\right.$ mol H$H^{+}$ton $)\left(\right.$mole $\mathrm{H}^{+} /$ton $)$ & $7.67 \pm 4.619$ & $3.67 \pm 1.155$ & 0.219 \\
\hline $\mathrm{TSA}\left(\mathrm{mol} \mathrm{H}^{+} /\right.$ton $)\left(\right.$mole $\mathrm{H}^{+} /$ton $)$ & $743.67 \pm 139.030$ & $1,159.67 \pm 188.696$ & 0.037 \\
\hline Pirit (Pyrite) (\%) & $3.33 \pm 0.608$ & $5.19 \pm 0.832$ & 0.036 \\
\hline Bahan organik (Organic matter) (\%) & $14.17 \pm 3.194$ & $19.60 \pm 4.182$ & 0.149 \\
\hline N-total (Total-N) (\%) & $0.3435 \pm 0.06543$ & $0.3736 \pm 0.02394$ & 0.495 \\
\hline Rasio C:N (C:N ratio) & $24.78 \pm 8.431$ & $30.740 \pm 8.287$ & 0.432 \\
\hline $\mathrm{PO}_{4}(\mathrm{mg} / \mathrm{L})$ & $18.5900 \pm 10.04191$ & $6.8567 \pm 1.63323$ & 0.096 \\
\hline $\mathrm{Fe}(\mathrm{mg} / \mathrm{L})$ & $4,660 \pm 34.5$ & $4,651 \pm 22.2$ & 0.733 \\
\hline $\mathrm{Al}(\mathrm{mg} / \mathrm{L})$ & $299 \pm 89.1$ & $444 \pm 170.9$ & 0.261 \\
\hline Pasir (Sand) (\%) & $90.67 \pm 1.155$ & $89.33 \pm 2.304$ & 0.422 \\
\hline Liat (Clay) (\%) & $5.33 \pm 1.155$ & $5.33 \pm 1.155$ & 1.000 \\
\hline Debu (Silt ) (\%) & $4.00 \pm 2.000$ & $5.33 \pm 3.055$ & 0.561 \\
\hline Nilai $\mathrm{n}$ ( $n$ value $)$ & $0.6365 \pm 0.06460$ & $0.7439 \pm 0.19041$ & 0.407 \\
\hline
\end{tabular}

Sebaliknya, ketersediaan berbagai unsur toksik seperti Fe, Al, dan Mn menjadi lebih rendah pada tanah vegetasi paku laut yang memiliki pH yang lebih mendekati netral. Oleh karena itu, dari kesuburan tanah maka tanah vegetasi paka laut dapat dijadikan indikator kesuburan tanah yang lebih tinggi daripada tanah vegetasi lainnya.

Komposisi jenis dan pertumbuhan mangrove secara langsung dipengaruhi oleh sifat fisik dari tanah (Ukpong, 1997; Hogart, 2007). Salah satu sifat fisik tanah yang mempengaruhi vegetasi mangrove adalah ukuran partikel atau tekstur tanah. Tekstur tanah di hutan mangrove Kabupaten Mamuju adalah pasir, pasir berlempung, dan lempung liat berpasir pada kedalaman 0-0,25 m, sedangkan tekstur pasir, pasir berlempung, dan lempung berpasir dijumpai pada kedalaman 0,50-0,75 m. Hasil analisis dari setiap fraksi dari tekstur tanah menunjukkan bahwa kandungan pasir tertinggi dijumpai pada tanah vegetasi api-api, baik pada kedalaman 0-0,25 m maupun 0,5-0,75 m. Telah banyak dilaporkan bahwa Avicennia sp. adalah vegetasi yang dijumpai tumbuh pada daerah yang terdekat dari laut pada substrat berpasir (Bengen, 2001; Hogart, 2007). Vegetasi lainnya (paku laut, bakau, nipah) tumbuh pada tanah dengan kandungan liat dan debu yang lebih tinggi daripada vegetasi api-api. Sebelumnya telah dilaporkan pula bahwa Rhizophora sp. merupakan vegetasi yang dominan di daerah dengan tanah berlumpur (Mustafa et al., 1988).

Nilai $\mathrm{n}$ tanah dapat menunjukkan daya tumpu (bearing capacity) tanah dan besarnya penurunan permukaan tanah atau amblesan (subsidence) tanah karena terkait dengan 
Tabel 7. Rata-rata nilai peubah kualitas tanah di bawah tegakan nipah pada kedalaman berbeda di Kabupaten Mamuju Provinsi Sulawesi Barat

Table 7. Average value of soil quality parameters under Nypa fruticans vegetation at different soil depths in Mamuju Regency West Sulawesi Province

\begin{tabular}{|c|c|c|c|}
\hline \multirow{2}{*}{$\begin{array}{l}\text { Peubah } \\
\text { Variable }\end{array}$} & \multicolumn{2}{|c|}{$\begin{array}{l}\text { Kedalaman } \\
\text { Depth (m) }\end{array}$} & \multirow[t]{2}{*}{$P$} \\
\hline & $0-0,25$ & $0,50-0,75$ & \\
\hline Potensial redoks (Redox potential) (mV) & $-115 \pm 85.7$ & $-163 \pm 22.6$ & 0.398 \\
\hline $\mathrm{pH}_{\mathrm{F}}$ & $6.52 \pm 0.387$ & $6.36 \pm 0.254$ & 0.872 \\
\hline $\mathrm{pH}_{\mathrm{FOx}}$ & $0.64 \pm 0.132$ & $0.70 \pm 0.356$ & 0.562 \\
\hline $\mathrm{pH}_{\mathrm{F}}-\mathrm{pH}_{\mathrm{FOX}}$ & $5.88 \pm 0.323$ & $5.66 \pm 0.362$ & 0.609 \\
\hline $\mathrm{pH}_{\mathrm{KCl}}$ & $4.96 \pm 0.772$ & $4.76 \pm 1.105$ & 0.936 \\
\hline $\mathrm{pH}_{\mathrm{ox}}$ & $1.71 \pm 0.860$ & $1.75 \pm 1.292$ & 0.114 \\
\hline $\mathrm{S}_{\mathrm{KCI}}(\%)$ & $1.25 \pm 0.427$ & $1.56 \pm 0.517$ & 0.596 \\
\hline$S_{p}(\%)$ & $11.82 \pm 5.056$ & $12.88 \pm 4.543$ & 0.235 \\
\hline $\mathrm{S}_{\mathrm{POS}}(\%)$ & $10.58 \pm 4.755$ & $11.32 \pm 4.660$ & 0.374 \\
\hline TPA $($ mol H+ ton $)\left(\right.$ mole $\mathrm{H}^{+} /$ton $)$ & $812.50 \pm 717.761$ & $1,068.67 \pm 951.757$ & 0.262 \\
\hline $\mathrm{TAA}\left(\mathrm{mol} \mathrm{H}^{+} /\right.$ton $)\left(\right.$mole $\mathrm{H}^{+} /$ton $)$ & $35.67 \pm 27.319$ & $26.67 \pm 21.733$ & 0.132 \\
\hline TSA (mol H+ton) (mole $\mathrm{H}^{+} /$ton $)$ & $776.83 \pm 690.719$ & $1,042.00 \pm 931.087$ & 0.256 \\
\hline Pirit (Pyrite) (\%) & $3.47 \pm 0.972$ & $4.65 \pm 1.096$ & 0.257 \\
\hline Bahan organik (Organic matter) (\%) & $16.82 \pm 13.596$ & $15.09 \pm 14.490$ & 0.664 \\
\hline N-total (Total-N) (\%) & $0.4384 \pm 0.17943$ & $0.3855 \pm 0.24455$ & 0.862 \\
\hline Rasio C:N (C:N ratio) & $19.65 \pm 10.633$ & $24.42 \pm 5.780$ & 0.740 \\
\hline $\mathrm{PO}_{4}(\mathrm{mg} / \mathrm{L})$ & $10.4000 \pm 4.69748$ & $10.9133 \pm 3.84360$ & 0.748 \\
\hline $\mathrm{Fe}(\mathrm{mg} / \mathrm{L})$ & $3,314 \pm 1,154.5$ & $4,559 \pm 121.2$ & 0.344 \\
\hline $\mathrm{Al}(\mathrm{mg} / \mathrm{L})$ & $168 \pm 114.3$ & $231 \pm 129.7$ & 0.439 \\
\hline Pasir (Sand) (\%) & $87.33 \pm 1.155$ & $87.33 \pm 1.155$ & 0.590 \\
\hline Liat (Clay) (\%) & $6.00 \pm 2.000$ & $6.00 \pm 2.000$ & 0.643 \\
\hline Debu (Silt ) (\%) & $6.67 \pm 3.055$ & $6.67 \pm 1.3155$ & 0.621 \\
\hline Nilai $\mathrm{n}$ ( $\mathrm{n}$ value $)$ & $0.8452 \pm 0.31820$ & $0.98157 \pm 0.52766$ & 0.838 \\
\hline
\end{tabular}

tingkat kematangan tanah. Hasil analisis ragam menunjukkan bahwa tidak ada perbedaan yang nyata antara nilai $\mathrm{n}$ pada jenis vegetasi yang berbeda. Akan tetapi berdasarkan kriteria yang dikemukakan oleh Pons \& Zonnevelds (1965) menunjukkan bahwa tanah pada vegetasi apiapi dengan kedalaman 0-0,25 m tergolong matang ( $\mathrm{d}$ " 0,7 ), sedangkan tanah pada vegetasi lainnya tergolong agak matang $(n=$ 0,7-1). Dalam hal ini, tanah pada vegetasi paku laut lebih mampu menahan beban dan lebih sedikit amblesannya dibandingkan jenis vegetasi lainnya, sehingga konstruksi tambak dapat dibuat lebih efisien. Dari Tabel 2 dan 3 juga terlihat bahwa ada kecenderungan berkurangnya nilai $\mathrm{n}$ mengikuti keberadaan vegetasi di Kabupaten Mamuju yang menjauhi laut. Vegetasi api-api dan bakau yang lebih dekat dari laut memiliki nilai $n$ yang lebih besar daripada vegetasi pakau laut dan nipah yang jauh dari laut. Semakin rendah nilai $n$ yang menunjukkan bahwa tanah lebih matang. Hasil yang sama telah dilaporkan oleh Sutrisno, 1990 dalam Noor, 2004 yang mengamati daerah Delta Pulau Petak (Kalimantan Selatan) yang menunjukkan bahwa perkembangan tanah semakin ke pedalaman (ke hulu sungai) dan menjauhi laut (muara sungai) semakin matang tanahnya dibandingkan dengan tanah yang berada di daerah pantai (ke hilir sungai).

Secara umum, perbedaan kedalalaman contoh tanah di masing-masing jenis vegetasi mangrove di Kabupaten Mamuju memperlihatkan tidak adanya perbedaan yang nyata pada vegetasi bakau dan nipah untuk semua peubah tanah yang dikaji dalam penelitian ini (Tabel 5, 6, 7). Diduga kedalaman tanah 0-0,25 
$\mathrm{m}$ dan 0,50-0,75 $\mathrm{m}$ pada vegetasi tersebut belum ada perbedaan kualitas tanah sebagai akibat perbedaan vegetasi atau perbedaan lingkungan lainnya. Perbedaan kualitas tanah pada kedalaman berbeda hanya dijumpai pada vegetasi paku laut dan api-api, itupun hanya pada peubah tanah tertentu (Tabel 4 dan 6). Vegetasi api-api dijumpai pada bagian terluar yaitu dekat laut yang memungkinkan tingginya dinamika perubahan lingkungan sebagai akibat perbedaan pasang surut, salinitas, arus air, lama penggenangan, dan frekuensi penggenangan. Nilai $\mathrm{pH}_{\mathrm{ox}}$ yang tinggi dan sebaliknya TPA, TSA, dan pirit yang rendah dijumpai pada kedalaman 0-0,25 m. Kemungkinan pengaruh perubahan lingkungan yang ekstrem di bawah vegetasi api-api hanya nyata pada kedalaman 0-0,25 m yang berdampak pada berkurangnya berbagai potensi kemasaman sebagai akibat pembilasan dalam waktu yang lama sehingga $\mathrm{pH}_{\text {ox }}$ menjadi lebih tinggi. Hal yang sama juga pada vegetasi paku laut yang sebelumnya secara umum merupakan lahan terbuka sehingga proses pembilasan unsur atau senyawa penyebab kemasaman telah berlangsung lama, sehingga kandungan unsur atau senyawa penyebab kemasaman telah berkurang. Kandungan $\mathrm{PO}_{4}$ yang rendah pada kedalaman 0,50-0,75 m diduga kuat terikat olef Al menjadi $\mathrm{AlPO}_{4}$ yang menjadi tidak terlarut.

\section{KESIMPULAN DAN SARAN}

Tegakan murni vegetasi mangrove di Kabupaten Mamuju, Provinsi Sulawesi Barat dijumpai pada vegetasi bakau (Rhizophora mucronata), api-api (Avicennia alba), dan nipah (Nypa fruticans), sedangkan paku laut (Acrosthicum aureum) adalah vegetasi mangrove yang tidak dapat membentuk tegakan murni dan semua vegetasi tersebut tumbuh pada tanah sulfat masam yang diklasifikasikan sebagai Sulfaquent dan Sulfihemits untuk kategori Kelompok Besar. $\mathrm{pH}_{\mathrm{F}}$ tanah pada vegetasi dan kedalaman tanah yang berbeda relatif sama, tetapi peubah kemasaman tanah lainnya menunjukkan bahwa tanah vegetasi paku laut menunjukkan potensi kemasaman yang lebih rendah dibandingkan dengan vegetasi lainnya. Kesuburan tanah berupa kandungan $\mathrm{PO}_{4}$ yang lebih tinggi dan sifat fisik tanah yang dicirikan dengan nilai $n$ d" 0,7 yang berarti tanah tergolong matang, menunjukkan tanah vegetasi paku laut lebih mendukung untuk lahan budidaya tambak daripada vegetasi lainnya (bakau, api-api, nipah).
Kualitas tanah pada setiap vegetasi relatif sama pada kedua kedalaman, kecuali tanah vegetasi paku laut yang memiliki $\mathrm{pH}$ dan kandungan $\mathrm{PO}_{4}$ yang lebih tinggi secara nyata pada kedalaman 0-0,25 m daripada 0,50-0,75 $\mathrm{m}$.

Keempat vegetasi yang dikaji dapat dijadikan indikator biologis keberadaan tanah sulfat masam, tetapi vegetasi paku laut memiliki kualitas tanah yang lebih baik untuk lahan budidaya tambak. Disarankan pula bahwa pengambilan contoh tanah untuk analisis di laboratorium pada tanah vegetasi bakau dan nipah yang belum diganggu tidak perlu pada kedalaman 0,5 m, kecuali untuk tujuan tertentu.

\section{UCAPAN TERIMA KASIH}

Terima kasih diucapkan kepada Muhammad Arnold dan Darsono atas bantuannya dalam pengambilan contoh tanah di lapangan serta Rosiana Sabang dan Rahmiyah atas bantuannya dalam analisis tanah di laboratorium.

\section{DAFTAR ACUAN}

Abdurachman, A., Haryati, U., \& Juarsah, I. 2006. Penetapan kadar air tanah dengan metode gravimetri. Dalam: Kurnia, U., Agus, F., Adimihardja, A., \& Dariah, A. (eds.), Sifat Fisik Tanah dan Metode Analisisnya. Balai Besar Penelitian dan Pengembangan Sumber Daya Lahan Pertanian, Bogor, hlm. 131-142.

ADB (Asian Development Bank). 1997. Mangrove Resources Development Plant: Lariang Coast, South Sulawesi, Indonesia (Volume Four). Development Alternative Inc., Bethesda, USA; SEATEC International Limited, Bangkok, Thailand; PT Aerokarto, Jakarta, Indonesia; PT Trans Intra Asia, Jakarta, Indonesia, 62 pp.

Ahern, C.R., Blunden, B., Sullivan, L.A., \& McElnea, A.E. 2004. Soil sampling, handling, preparation and storage for analisys of dried samples. In: Acid Sulfate Soils Laboratory Methods Guidelines. Queensland Department of Natural Resources, Mines and Energy, Indooroopilly, Queensland, Australia, p. B1-1-B1-5.

Ahern, C.R. \& McElnea, A.E. 2004. Calculated sulfur parameters. In: Acid Sulfate Soils Laboratory Methods Guidelines. Queensland Department of Natural Resources, Mines and Energy, Indooroopilly, Queensland, Australia, p. B11-1-B11-2. 
Ahern, C.R., McElnea, A.E., \& Baker, D.E. 1998a. Peroxide oxidation combined acidity and sulfate. In: Ahern, C.R., Blunden, B., \& Stone, Y. (eds.), Acid Sulfate Soils Laboratory Methods Guidelines. Acid Sulfate Soil Management Advisory Committee, Wollongbar, NSW, p. 4.1-4.17.

Ahern, C.R., McElnea, A.E., \& Baker, D.E. 1998b. Total oxidisable sulfur. In: Ahern, C.R., Blunden, B., \& Stone, Y. (eds.), Acid Sulfate Soils Laboratory Methods Guidelines. Acid Sulfate Soil Management Advisory Committee, Wollongbar, NSW, p. 5.1-5.7.

Barchia, M.F. 2006. Gambut: Agroekosistem dan Transformasi Karbon. Gadjah Mada University Press, Yogyakarta, $196 \mathrm{hlm}$.

Bengen, D.G. 2001. Struktur dan Dinamika Eksositem Pesisir dan Laut. Institut Pertanian Bogor, Bogor, $66 \mathrm{hlm}$.

Boyd, C.E. 2008. Pond bottom soil analyses. Global Aquaculture Advocate September/ October: 91-92.

Dent, D. 1986. Acid Sulphate Soils: A Baseline for Research and Development. ILRI Publication 39. International Institute for Land Reclamation and Improvement, Wageningen, $204 \mathrm{pp}$.

English, S., Wilkinson, C., \& Basker, V. 1997. Survey Manual for Tropical Marine Resources. Second edition. Australian Institute of Marine Science, Townsville, p. 119 195.

Ferreira, T.O., Otero, X.L., Vidal-Torrado, P., \& Macías, F. 2007. Redox processes in mangrove soils under Rhizophora mangle in relation to different environmental conditions. Soil Science Society of America J., 71: 484-491.

Hanafiah, K.A. 2005. Dasar-dasar Ilmu Tanah. PT Raja Grafindo Persada, Jakarta, $360 \mathrm{hlm}$.

Hardjowigeno, S. 2003. Klasifikasi Tanah dan Pedogenesis. Edisi revisi. Akademika Pressindo, Jakarta, $354 \mathrm{hlm}$.

Hogart, P. 2007. The Biology of Mangroves and Seagrasses. Second edition. Oxford University Press, Oxford, $273 \mathrm{pp}$.

Jordan, H.D. 1964. The relation of vegetation and soil to development of mangrove swamps for rice growing in Sierra Leone. J. of Applied Ecology, 1(1): 209-212.

Karthik, M., Suri, J., Saharan, N., \& Biradar, R.S. 2005. Brackish water aquaculture site selection in Palghar Taluk, Thane district of Maharashtra, India, using the techniques of remote sensing and geographical in- formation system. Aquacultural Engineering, 32: 285-302.

Koch, B.P. 2005. Organic Matter Pathways in a Mangrove System in Northen BrazilChemical Tracers of Major Sources under the Influence of Sedimentation and Biological Degradation. Center for Tropical Marine Ecology, Bremen, 109 pp.

Lacerda, L.D., Ittekkot, V., \& Patchineelam, S.R. 1995. Biogeochemistry of mangrove soil organic matter: a comparison between Rhizophora and Avicennia soils in Southeastern Brazil. Estuarine, Coastal and Shelf Science, 40(6): 713-720.

Matthijs, S., Tack, J., van Speybroeck, D., \& Koedam, N. 1999. Mangrove species zonation and soil redox state, sulphide concentration and salinity in Gazi Bay (Kenya), a preliminary study. Mangrove and Salt Marshes, 3(4): 243-249.

McElnea, A.E. \& Ahern, C.R. 2004a. KCl extractable $\mathrm{pH}\left(\mathrm{pH}_{\mathrm{KC}}\right)$ and titratable actual acidity (TAA). In: Acid Sulfate Soils Laboratory Methods Guidelines. Queensland Department of Natural Resources, Mines and Energy, Indooroopilly, Queensland, Australia, p. B2-1-B2-3.

McElnea, A.E. \& Ahern, C.R. 2004b. Peroxide $\mathrm{pH}\left(\mathrm{pH}_{\mathrm{OX}}\right)$, titartable peroxide acidity (TPA) and excess acid neutralising capacity $\left(\mathrm{ANC}_{\mathrm{E}}\right.$ ). In: Acid Sulfate Soils Laboratory Methods Guidelines. Queensland Department of Natural Resources, Mines and Energy, Indooroopilly, Queensland, Australia, p. B3-1-B3-7.

McElnea, A.E. \& Ahern, C.R. 2004c. Sulfurperoxide oxidation method. In: Acid Sulfate Soils Laboratory Methods Guidelines. Queensland Department of Natural Resources, Mines and Energy, Indooroopilly, Queensland, Australia, p. B7-1-B7-2.

McElnea, A.E. \& Ahern, C.R. 2004d. Sulfur 1 M $\mathrm{KCl}$ extraction $\left(\mathrm{S}_{\mathrm{KCl}}\right)$. In: Acid Sulfate Soils Laboratory Methods Guidelines. Queensland Department of Natural Resources, Mines and Energy, Indooroopilly, Queensland, Australia, p. B8-1-B8-2.

McElnea, A.E., Ahern, C.R., \& Menzies, N.W. 2002a. Improvements to peroxide oxidation methods for analyzing sulfur in acid sulfate soils. Australian J. of Soil Research, 40: $1115-1132$.

McElnea, A.E., Ahern, C.R., \& Menzies, N.W. $2002 \mathrm{~b}$. The measurement of actual acidity in acid sulfate soils and the determination 
of sulfidic acidity in suspension after peroxide oxidation. Australian J. of Soil Research, 40: 1133-1157.

Melville, M.D. 1993. Soil Laboratory Manual. School of Geography, The University of New South Wales, Sydney, 74 pp.

Mustafa, A. 1998. Budi daya tambak di lahan gambut dan permasalahannya: studi kasus di Sulawesi Selatan. J. Litbang Pertanian, XVII(3): 73-82.

Mustafa, A., Ahmad, T., \& Cholik, F. 1988. Vegetasi hutan mangrove di Kecamatan Bone-bone, Kabupaten Luwu, Sulawesi Selatan. J. Penelitian Budidaya Pantai, 4(1): 104-118.

Mustafa, A., Hanafi, A., Pantjara, B., \& Suwardi. 1994. Karakteristik lahan mangrove di Delta Tampinna, Kabupaten Luwu, Sulawesi Selatan. Dalam: Mansur, H., Rachmansyah, Atmomarsono, M., \& Mustafa, A. (eds.), Risalah Seminar Hasil Penelitian Perikanan Budidaya Pantai. Balai Penelitian Perikanan Budidaya Pantai, Maros, hlm. 95-105.

Mustafa, A. \& Sammut, J. 2007. Effect of different remediation techniques and dosages of phosphorus fertilizer on soil quality and klekap production in acid sulfate soilaffected aquaculture ponds. Indonesian Aquaculture J., 2(2): 141-157.

Noor, M. 2004. Lahan Rawa: Sifat dan PengeIolaan Tanah Bermasalah Sulfat Masam. PT Raja Grafindo Persada, Jakarta, $238 \mathrm{hlm}$.

Noor, M. 2007. Rawa Lebak: Ekologi, Pemanfaatan, dan Pengembangannya. PT Raja Grafindo Persada, Jakarta, $274 \mathrm{hlm}$.

Patrick, W.H.Jr. \& Delaune, R.D. 1977. Chemical and biological redox systems affecting nutrient availability in the coastal wetlands. Geoscience and Man., 18:131-137.

Pons, L.J. 1973. Outline of genesis, characteristics, classification and improvement of acid sulphate soil. In: Dost, H. (ed.), Acid Sulphate Soils. ILRI Publication 18. International Institute for Land Reclamation and Improvement, Wageningen, p. 1-27.

Pons, L.J. \& Zonneveld, I.S. 1965. Soil Ripening and Soil Classification: Initial Soil Formation of Alluvial Deposits with a Classification of the Resulting Soil. ILRI Publication 13. International Institute for Land Reclamation and Improvement, Wageningen, 128 pp.

Sammut, J. \& Lines-Kelly, R. 2000. An Introduction to Acid Sulfate Soils. Natural Heritage Trust, Australia, $27 \mathrm{pp}$.
Schaetzl, R.J. \& Anderson, S. 2005. Soils: Genesis and Geomorphology. Cambridge University Press, Cambridge, $817 \mathrm{pp}$.

Sediadi, A. \& Pramudji. 1987. Penelitian kecepatan gugur daun dan penguraiannya dalam hutan bakau di Teluk Ambon. Dalam: Soerianegara, I., Adisoemarto, S., Soemodihardjo, S., Hardjowigeno, S., Sudomo, M., \& Ongkosongo, O.S.R. (eds.), Prosiding Seminar III Ekosistem Mangrove. Panitia Program MAB Indonesia-Lembaga Ilmu Pengetahuan Indonesia, Jakarta, hlm. 110-114.

Soil Survey Staff. 2001. Soil Taxonomy, a Basic System of Soil Classification for Making and Interpreting Soil Survey. United State Department of Agriculture, Washington, D.C., 734 pp.

SPSS (Statistical Product and Service Solution). 2006. SPSS 15.0 Brief Guide. SPSS Inc., Chicago, $217 \mathrm{pp}$.

Subagyo, A. 2006. Lahan rawa lebak. Dalam: Ardi, D.S. (ed.), Karakteristik dan PengeIolaan Lahan Rawa. Balai Besar Penelitian dan Pengembangan Sumber Daya Lahan Pertanian, Bogor, hlm. 99-116.

Sulaeman, Suparto, \& Eviati. 2005. Petunjuk Teknis Analisis Kimia Tanah, Tanaman, Air, dan Pupuk. Diedit oleh: Prasetyo, B.H., Santoso, D., \& Widowati, L.R. Balai Penelitian Tanah, Bogor, $136 \mathrm{hlm}$.

Sunarto. 2008. Peranan Ekologis dan Antropogenesis Ekosistem Mangrove. Karya IImiah. Fakultas Perikanan dan IImu Kelautan, Universitas Padjadjaran, Jatinangor, $34 \mathrm{hlm}$.

Ukpong, I.E. 1995. Vegetation and soil acidity of a mangrove swamp in southeastern Nigeria. Soil Use and Management, 11 (3): 141-144.

Ukpong, I.E. 1997. Vegetation and its relation to soil nutrient and salinity in the Calabar mangrove swamp, Nigeria. Mangroves and Salt Marshes, 1(4): 211-218.

Woodroffe, C.D. 1982. Litter production and decomposition in the New Zealand mangrove Avicennia marina var resinifera. New Zealand J. of Marine and Freshwater Research, 16: 179-188.

Zhang, W., Faulkner, J.W., Giri, S.K., Geohring, L.D., \& Steenhuis, T.S. 2009. Effect of soil reduction on phosphorus sorption of an organic-rich silt loam. Soil Science Society of America J., 74: 240-249. 